\title{
Distribution of Salmonella serovars and characterization of isolates in cattle feces and environmental samples
}

\author{
Melih ÇAKIN ${ }^{\mathrm{a}, \bigotimes}$, Beren BAŞARAN KAHRAMAN ${ }^{\mathrm{b}}$, Belgi DİREN SIĞIRCI \\ Arzu Funda BAĞCIGiL' \\ İstanbul University Cerrahpasa, Faculty of Veterinary Medicine, Department of Microbiology, İstanbul, Turkey \\ aORCID: 0000-0002-9145-1338; ' ${ }^{\mathrm{O} O R C I D: ~ 0000-0002-1736-093 X ; ~ ' O R C I D: ~ 0000-0001-7153-7428 ; ~}$ \\ ${ }^{\mathrm{d} O R C I D:}$ 0000-0002-8838-7291 \\ ${ }^{\otimes}$ Corresponding author: melihcakin@ hotmail.com \\ Received date: 13.03.2019 - Accepted date: 30.12.2019
}

\begin{abstract}
In this study, it was aimed to identify the presence of Salmonella serovars, and investigate the antibiotic susceptibility of isolates and the presence of certain virulence factors in the samples collected from cattle feces and environmental samples. Fecal and environmental swab samples were regularly collected from five different dairy cattle farms for a period of one year, once in each season. Totally, 425 fecal samples from animals, 21 of which had diarrhea and 400 environmental samples were examined for Salmonella spp.. While no Salmonella spp. was isolated from the environmental samples, Salmonella spp. was isolated from three $(0.36 \%)$ of the fecal samples. All isolates were isolated from a single farm and they were sampled in autumn. Two strains were serotyped as $S$. Kottbus and the other as $S$. Lindenburg. All serovars were found to be sulfamethoxazole-resistant, while susceptible to cefoxitin, nalidixic acid, trimethoprim-sulfamethoxazole, enrofloxacin, ciprofloxacin, ceftriaxone, ceftiofur and amoxicillin-clavulanic acid. While $m g t \mathrm{C}$, misL and invA were detected in all isolates, no pefA was detected. stn was detected in $S$. Lindenburg and one of $S$. Kottbus, whereas the $s p v$ A was detected only in $S$. Lindenburg. Presence of isolation only in one of the five farms and the low isolation rates were associated with a good level of biosecurity measures in the area where the study was conducted. Salmonella spp. isolation from healthy animals apart from animals with diarrhea was found to be important in terms of the role that persistently infected animals can play in the spread of the agent.
\end{abstract}

Keywords: Cattle, environmental contamination, feces, PCR, Salmonella spp.

\section{Sığır dışkılarında ve çevresel örneklerde Salmonella serovarlarının dağılımı ve izolatların karakterizasyonu}

Özet: Bu çalışmada sığır dışkılarından ve işletmelerin çevresel ortamlarından toplanan örneklerde Salmonella serovarlarının varlığının belirlenmesi, izolatların antibiyotik duyarlılıklarının ve belirli virülens faktörlerinin varlığının araştırılması amaçlandı. Beş farklı süt sı̆̆ırı işletmesinden bir yıl boyunca her mevsim döneminde bir kez olmak üzere düzenli olarak dışkı ve çevresel svap örnekleri toplandı. Yirmi bir tanesi ishalli hayvanlardan olmak üzere 425 adet dışkı ve 400 adet çevresel svap örneği Salmonella spp. yönünden incelendi. Çevresel örneklerin hiç birisinden Salmonella spp. izole edilmezken, dışk1 örneklerinin üç tanesinden $(\% 0,36)$ Salmonella spp. izole edildi. İzolatların hepsi tek bir işletmeden ve sonbahar döneminde izole edildi. İki suş $S$. Kottbus ve diğeri $S$. Lindenburg olarak serotiplendi. Serovarların tamamı sulfamethoksazol dirençli, sefoksitin, nalidiksik asid, trimethroprim-sulfamethoksazol, enrofloksasin, siprofloksasin, seftriakson, seftiofur ve amoksisilin-klavulanik aside duyarlı bulundu. $m g t \mathrm{C}$, $m i s \mathrm{~L}$ ve invA genleri tüm izolatlarda saptanırken, pefA geni izolatların hiçbirinde saptanmadı. stn virulens faktörü S. Lindenburg ve bir adet S. Kottbus serovarında, $s p v$ A virulens faktörü ise sadece S. Lindenburg serovarında saptandı. Çalışmaya dahil edilen beş adet işletmeden sadece birinde izolasyon olması ve izolasyon oranlarının düşük seviyelerde kalması çalışmanın yapıldığı bölgedeki biyogüvenlik önlemlerinin iyi bir seviyede olmasıyla ilişkilendirilmiştir. İshalli hayvanların yanında sağlıklı hayvan dışkılarından da Salmonella spp. izole edilmesi, persiste infekte hayvanların etkenin saçılımında oynayabilecekleri rol açısından önemli bulunmuştur.

Anahtar sözcükler: Çevresel kontaminasyon, dışkı, PCR, Salmonella spp., sığır. 


\section{Introduction}

Salmonella species are Gram-negative, non-spore, and facultative anaerobic bacilli belonging to the Enterobacteriaceae family (8). They can lead to zoonotic infections that can be accompanied by high mortality in the vertebrate creatures they colonize (7). Farm animals can be a source of salmonellosis seen in humans. Increasing yields, unconscious and high rates of antibiotic use in treatments lead to rapidly increasing drug resistance among Salmonella serovars. This rapid spread has resulted in difficulties in the treatment of infectious diseases in humans and animals and has reached to an extent that threatens the public health (1). The severity of infections caused by Salmonella serovars shows variations. Virulence factors owned by serovars, each of which has a function in different mechanisms, are responsible for this. Studies on isolates obtained from farm animals often identified the invA gene responsible for the bacterial invasion of cells, the pefA gene, one of the genes encoding the fimbriae active in adhesions, the mis $\mathrm{L}$ gene, one of the non-fimbrial components active in adhesions, the $m g t \mathrm{C}$ gene responsible for the proliferation of bacteria in the intracellular environments with intense magnesium concentration, the stn gene responsible for toxin production and virulence factors such as the Salmonella virulence plasmids ( $s p v \mathrm{~A}, s p v \mathrm{~B}, s p v \mathrm{C}, s p v \mathrm{R})$ that play a role in causing the agent to form systemic infections $(1,4$, 16).

Most of the studies conducted in our country to detect Salmonella serovars in cattle focus on the distribution of Salmonella serovars in cattle carcasses or animal products produced as food. However, it is emphasized that the feces of livestock may also be an important source of contamination. For this reason, in this study, the presence of Salmonella and the distribution of serovars were investigated in fecal samples. It was aimed to investigate the antibiotic susceptibility of isolates and to obtain epidemiological data by investigating the presence of important virulence factors.

\section{Material and Methods}

In the study, enviromental swabs and fresh fecal samples were collected four times in each season within a one-year period from 5 dairy product farms in Istanbul and surrounding areas. Samples were collected once in each season. In addition to animals displaying diarrhea signs in each farm, samples of 20 healthy animal feces were also randomly collected. This study was approved by İstanbul University Animal Experiments Local Ethics Board (Decision no: 2013/120).

Enviromental samples listed in Table 1, were collected via sterile swabs and delivered to the laboratory on the same day as the transport mediums. Salmonella isolation from samples was carried out according to the World Health Organization's protocol of Isolation of Salmonella spp. from Food and Animal Faeces (ISO6579) (30). Briefly, Buffered peptone water used for preenrichment. Tetrathionate broth (TTB), Rappaport Vassiliadis broth (RVS), Xylose Lysine Deoxycholate Agar (XLD), Brillant Green Agar (BG), MacConkey Agar were used in isolation stage. In addition to the protocol, novobiocin $(15 \mu \mathrm{g} / \mathrm{ml}$ final concentration) added Hektoen Enteric Agar (HEA) was also used in the isolation. The identification was made according to the World Health Organization's laboratory protocol for the identification of Salmonella and Shigella by shortened panel tests (31). Serovar identifications of the isolates identified as Salmonella spp. were performed at Veterinary Control Central Research Institute. Antibiotic susceptibility of the

Table 1. List of environmental samples.

\begin{tabular}{lllll}
\hline \multicolumn{1}{c}{ Farm A } & \multicolumn{1}{c}{ Farm B } & \multicolumn{1}{c}{ Farm C } & \multicolumn{1}{c}{ Farm D } & \multicolumn{1}{c}{ Farm E } \\
\hline Cabin for preparing pulp & Fence (7) & Milk container (2) & Barn floor (11) & Wheelbarrow (3) \\
Tractor wheel & Brush & Metal barrel (4) & Waterer (4) & Water booster \\
Trailer wheel & Barn floor (5) & Pump of milking machine (2) & Fence (2) & Wall of milking parlour \\
Automatic surface scraper & Chain of scraper (2) & Garden rake (2) & Chain of scraper & Dredge \\
Dog paw (2) & Waterer (2) & Coveralls & Barn door & Pump of milking machine (2) \\
Boot (2) & Barn wall & Milk boiler & Shovel & Ramp of milking parlour \\
Pump of milking machine & Hose & Circuit breaker & & Satairs of milking parlour \\
Ventilation & Boot & Tractor Wheel & Chain of scraper \\
Command of scraper & & Gutter & Barn wall (3) \\
Broom & & Tap & & Fence (3) \\
Milk tank & & Milking parlour door & Shovel \\
Manger (2) & & Manger & Vacuum motor \\
Waterer (2) & Wheelbarrow & & Brush \\
Barn door & Barn floor & & \\
Mop & & & \\
Stairs of milking parlour & & & & \\
\hline
\end{tabular}

The number of samples is indicated in parentheses. Unless otherwise indicated, only one sample was collected. 
Table 2. Primer sequences and amplicon size, annealing temperatures for PCR assays.

\begin{tabular}{|c|c|c|c|c|}
\hline Gene region & Primer sequence & $\begin{array}{l}\text { Annealing } \\
\text { temperature }\end{array}$ & $\begin{array}{l}\text { Amplicon } \\
\text { size }\end{array}$ & Reference \\
\hline $\operatorname{inv} \mathrm{A}$ & $\begin{array}{l}\text { 5'- ACAGTGCTCGTTTACGACCTGAAT -3' } \\
\text { 5'- AGACGACTGGTACTGATCCGATAAT -3' }\end{array}$ & $56^{\circ} \mathrm{C}$ & $244 \mathrm{bp}$ & Chiu and $\mathrm{Ou}(3)$ \\
\hline stn & $\begin{array}{l}\text { 5'- TTGTGTCGCTATCACTGGCAACC -3' } \\
\text { 5'- ATTCGTAACCCGCTCTCGTCC -3' }\end{array}$ & $59^{\circ} \mathrm{C}$ & $617 \mathrm{bp}$ & $\begin{array}{l}\text { Murugkar et al. } \\
\text { (17) }\end{array}$ \\
\hline pefA & $\begin{array}{l}\text { 5'- TGTTTCCGGGCTTCTGCTG -3' } \\
\text { 5'- CAGGGCATTTGCTGATTCTTCC -3' }\end{array}$ & $55^{\circ} \mathrm{C}$ & $700 \mathrm{bp}$ & $\begin{array}{l}\text { Murugkar et al. } \\
\text { (17) }\end{array}$ \\
\hline$m g t \mathrm{C}$ & $\begin{array}{l}\text { 5'- TGACTATCAATGCTCCAGTGAAT -3' } \\
\text { 5'- ATTTACTGGCCGCTATGCTGTTG -3' }\end{array}$ & $60^{\circ} \mathrm{C}$ & $655 \mathrm{bp}$ & Soto et al. (25) \\
\hline$m i s \mathrm{~L}$ & $\begin{array}{l}\text { 5'- GACGTTGATAGTCTGCCATCCAG -3' } \\
\text { 5'- CAATGCCGCCAGTCTCCGTGC -3' }\end{array}$ & $60^{\circ} \mathrm{C}$ & 986 bp & Soto et al. (25) \\
\hline$s p v \mathrm{~A}$ & $\begin{array}{l}\text { 5'- GTCAGACCCGTAAACAGT -3, } \\
\text { 5'- GCACGCAGAGTACCCGCA -3, }\end{array}$ & $60^{\circ} \mathrm{C}$ & $604 \mathrm{bp}$ & Guerra et al. (13) \\
\hline
\end{tabular}

isolates was investigated by the disc diffusion method according to CLSI standards $(5,6)$. After the serovar identification was performed, each isolate was examined by PCR for the presence of invA, mgtC, misL, stn, pefA, and spvA virulence factors. Salmonella Typhimurium ATCC 14028 from culture collection of Istanbul University Cerrahpasa Faculty of Veterinary Medicine, Department of Microbiology was used as the positive control. DNA extraction was performed according to the protocol by Eyigor et al. (11). HOT FIREPol® DNA Polymerase [Solis BioDyne, Tartu, Estonia, Cat. no. 01-

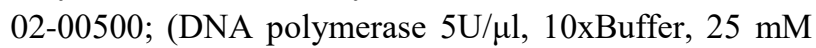
$\mathrm{MgCl}_{2}$, dNTP mix (20 mM of each)] was used. The primers used in the study, their sequences, PCR programs etc. are given in Table 2 .

\section{Results}

Salmonella spp. was isolated from three $(0.36 \%)$ of 425 fecal samples at five farms. Two of the serovars were identified as Salmonella enterica subsp. enterica serovar Kottbus ( $S$. Kottbus) and the other one as $S$. Lindenburg. Agent isolation took place only in one of the five farms examined. In terms of the total number of samples $(n=88)$ examined in this farm, the isolation rate was found to be $3.4 \%$. Salmonella was not isolated from 400 environmental samples. Diarrhea was observed in 21 cattle from which fecal samples were collected. $S$. Kottbus (D3-38) was isolated from one of these cattle (4.7\%). $S$. Lindenburg (D3-26) and the other $S$. Kottbus (D3-33) serovar were isolated from healthy animals that did not display any clinical signs. When the isolation rates were examined seasonally, it was observed that all isolations occurred in autumn. Antibiotic susceptibility of serovars examined by disk diffusion is given in Table 3.

As a result of the PCR, $m g t \mathrm{C}$, mis $\mathrm{L}$ and $i n v \mathrm{~A}$ genes were detected in all isolates, but pefA was not detected. stn was detected in $S$. Lindenburg and one of $S$. Kottbus, whereas the $s p v \mathrm{~A}$ virulence factor was detected only in a $S$. Lindenburg serovars. PCR results of serovars are given in Table 3.

Table 3. Characterization of isolates.

\begin{tabular}{|c|c|c|c|c|}
\hline $\begin{array}{l}\text { Serovar } \\
\text { (Sample code) }\end{array}$ & & $\begin{array}{c}S . \\
\text { Lindenburg } \\
(\text { D3-26) }\end{array}$ & $\begin{array}{c}S . \\
\text { Kottbus } \\
\text { (D3-33) }\end{array}$ & $\begin{array}{c}S . \\
\text { Kottbus } \\
\text { (D3-38) }\end{array}$ \\
\hline \multirow{14}{*}{$\begin{array}{c}\text { Antibiotic } \\
\text { susceptibility }\end{array}$} & AMP & $\mathrm{R}$ & S & S \\
\hline & AMC & $S$ & $S$ & $S$ \\
\hline & EFT & $S$ & I & I \\
\hline & CTR & S & $S$ & S \\
\hline & $\mathrm{C}$ & $\mathrm{R}$ & $\mathrm{R}$ & $\mathrm{R}$ \\
\hline & CIP & S & S & $S$ \\
\hline & ENR & $S$ & $S$ & $S$ \\
\hline & $\mathrm{CN}$ & $\mathrm{R}$ & S & $S$ \\
\hline & $\mathrm{S}^{*}$ & $\mathrm{R}$ & $S$ & I \\
\hline & $\mathrm{TE}$ & $\mathrm{R}$ & S & I \\
\hline & SXT & S & S & $S$ \\
\hline & SX & $\mathrm{R}$ & $\mathrm{R}$ & $\mathrm{R}$ \\
\hline & NA & S & S & $S$ \\
\hline & CX & S & $S$ & S \\
\hline \multirow{6}{*}{$\begin{array}{l}\text { Virulance } \\
\text { factors }\end{array}$} & $m g t \mathrm{C}$, & + & + & + \\
\hline & $m i s \mathrm{~L}$ & + & + & + \\
\hline & $\operatorname{inv} \mathrm{A}$ & + & + & + \\
\hline & pefA & - & - & - \\
\hline & $s t n$ & + & + & - \\
\hline & $s p v \mathrm{~A}$ & + & - & - \\
\hline
\end{tabular}

S: Susceptible; I: Moderately Susceptible; R: Resistant; AMP: Ampicillin $(10 \mu \mathrm{g})$, AMC: Amoxicillin-Clavulanic Acid $(20 / 10 \mu \mathrm{g})$; EFT: Ceftiofur $(30 \mu \mathrm{g})$, CTR: Ceftriaxone $(30 \mu \mathrm{g})$, C:Chloramphenicol $(30 \mu \mathrm{g})$; CIP: Ciprofloxacin $(5 \mu \mathrm{g})$; ENR: Enrofloxacin $(5 \mu \mathrm{g})$; CN: Gentamicin $(10 \mu \mathrm{g}) ; \mathrm{S}^{*}$. Streptomycin $(10 \mu \mathrm{g})$; TE: Tetracycline $(30 \mu \mathrm{g})$; SXT: Trimethoprim sulfamethoxazole $(1.25 / 23.7 \mu \mathrm{g})$; SX: Sulfamethoxazole $(25 \mu \mathrm{g})$; NA: Nalidixic acid $(30 \mu \mathrm{g})$; CX: Cefoxitin $(30 \mu \mathrm{g})$. 


\section{Discussion and Conclusion}

In this study, isolation rate of Salmonella spp. from 425 fecal samples was $0.36 \%$. It is seen that these rates differ in similar studies like Warnick et al. (28) $9.3 \%$; Donkersgoed et al. (9) 0.08\%; and McEvoy et al. (15) $2 \%$. In our study, all of the isolations were performed in a single farm. This farm was found to be far behind in terms of compliance with hygiene requirements compared to others, and it was thought that this could be affecting the isolation rates. Warnick et al. (28) and Murinda et al. (17) isolated $12.9 \%$ and $3.76 \%$ Salmonella spp., respectively from the environmental samples in the dairy cattle farms. In this study, Salmonella was not isolated from any of the 400 swab samples. This was associated with the good hygiene and biosecurity measures of the farms.

The seasonal factors, which are thought to have an effect on the isolation rates have been evaluated by many researchers. Pangoli et al. (22) pointed to the parallelism between seasonal temperature increase and isolation rates. On a seasonal basis, McEvoy et al. (15) obtained the highest isolation rate in autumn, but Nothingham and Urselmann (18) in spring. Researchers did not evaluate the temperature difference as the sole criterion, but they also referred to different factors. Salmonella spp. isolation was only carried out from the samples collected at the beginning of November when the average temperature was $11.7^{\circ} \mathrm{C}$ in the autumn. In this period temperature was higher than winter months, precipitation and the humidity were higher than summer months. This result was supporting the researchers by whom claiming isolation rates could be higher in spring months when heat, precipitation and humidity is higher than the other seasons of the year.

One of the factors affecting isolation rates when working with contaminated materials such as feces was reported as the selectivity of the medium used. Alcaide et al. (2) reported that their isolation rates were higher than BSA and HEA, and BG agar was less effective in inhibiting competitive microorganisms. They performed most of the isolations in the study with HEA. Studies in which different mediums are used have shown that HEA medium has a more selective quality even though it does not provide higher isolation rates. Jensen et al. (14) reported that novobiocin additions into mediums increased isolation rates. In this study, all of the isolations were carried out with novobiocin added HEA and it was found to be particularly useful for increasing the isolation chance of Salmonella species from contaminated materials such as feces.

Palmera-Suarez et al. (21) reported that $S$. Kottbus was detected in bottled waters and that the consumption of bottled water in human cases played a role. They reported parrots as a contamination source of waters. $S$. Kottbus was isolated via several different sources, including poultry, cattle, pig, the environment and human between 2000 and2011 (26). Özsan et al. (20) isolated $S$. Lindenburg from wild rodents in Central Anatolia. $S$. Kottbus and $S$. Lindenburg have been reported as serovars obtained from both human and non-human sources (27). Isolation of $S$. Lindenburg and $S$. Kottbus serovars from cattle in this study indicates that cattle may be a source of contamination.

In the current study, all serovars were resistant to sulphamethoxazole, they were susceptible to cefoxitin, nalidixic acid, trimethoprim-sulphamethoxazole, enrofloxacin, ciprofloxacin, ceftriaxone, ceftiofur and amoxicillin-clavulanic acid. Similar to our study, Wells et al. (29) found resistance to ceftiofur, ceftriaxone and ciprofloxacin. Sulphamethoxazole resistance was found to be as low as $2.9 \%$ compared to this study. Fluckey et al. (12) and Duffy et al. (10) found sulfamethoxazole resistance at a high rate $(96.08 \%)$ in parallel with this study. The data of Hygiene Center reported that $S$. Kottbus serovars were resistant to tetracycline, nalidixic acid, trimethoprim- sulfamethoxazole and ampicillin at the rates of $9.7 \%, 12.2 \%, 17.0 \%$ and $9.7 \%$, respectively (14). However, tetracycline, nalidixic acid, trimethoprimsulfamethoxazole and ampicillin resistance were not observed among $S$. Kottbus serovars in this study.

mis $\mathrm{L}$ is a gene region that plays an important role in adhesion and is significant for the bacteria to form systemic infections by sticking to the intestinal tract (24). $m g t \mathrm{C}$ plays a role in the formation of systemic infections by allowing bacteria to survive in low magnesium concentrations in the cell (23). mis L and $m g t \mathrm{C}$ virulence factors were detected in all serovars. The role of these factors in bringing about systemic infections should not be ignored in terms of public health. Many researchers have investigated the presence of the invA virulence factor in Salmonella and found high rates $(4,7,8)$. Because of this feature, they thought that this factor could be a rapid, unique and sensitive tool for the detection of Salmonella $(8,19)$. In this study, invA was detected in all serovars. pef $\mathrm{A}$ is one of the genes encoding the fimbriae that play a role in adhesion (16). Murugkar et al. (16) reported that their role in the pathogenesis of the pef genes is still unclear. Chuanchuen et al. (4) reported that the mutation in the pef A gene did not bring about a significant change in virulence. No pefA gene was detected in this study. Stn is a virulence factor associated with toxin production that play a role in the development of diarrhea (16). In this study, stn gene was detected from cattle without diareae so it was not detected connection between stn gene and diarrhea. The genes found in the $s p v$ operon increase virulence of serovars and lead to lethal infections. There are studies suggesting a direct link between virulence plasmid and multiple antibiotic resistances In this study, $s p v$ A was detected only in the $S$. Lindenburg serovar. 
When the resistance levels of two serovars against antibiotics were compared, it was found that $S$. Lindenburg serovar was resistant higher number of antibiotics than $S$. Kottbus. This is remarkable in terms of correlation that can be established between $s p v \mathrm{~A}$ and resistance level.

In this study, two serovars, $S$. Kottbus and $S$. Lindenburg were isolated. The fact that $S$. Kottbus has been reported in infections in newborn units abroad at different times shows its importance in terms of public health. $S$. Lindenburg has been isolated from wild-rodents in our country, which is worrying about the spread and localization of the agent via wild-rodents at farms with inadequate biosecurity practices. Both serovars carry virulence factors like $m g t \mathrm{C}$ and $m i s \mathrm{~L}$ that play a role in the development of systemic infections. This is remarkable in terms of the seriousness of infections that may occur in a possible epidemic. spvA virulence factor has been associated with multiple antibiotic resistance by some investigators. In the present study, spvA was detected in the $S$. Lindenburg serovar. According to the antibiogram result, the $S$. Lindenburg serovar exhibited a much more resistant picture than the $S$. Kottbus serovar and this is noteworthy, because it could pose significant risks to animal and human health with the way of causing infections difficult to treat by antibiotics especially in young individuals. That only one of the five farms included in the study had isolation and that isolation remained at low levels were associated with sufficient level of biosecurity measures in the Thrace region. The isolation taking place in healthy animal feces apart from animals with diarrhea show that persistently infected animals could spread the agent. Since there is limited data on the prevalence of Salmonella in live dairy cattle, one of the sources of foodborne Salmonella infections in our country, similar studies need to be continued.

\section{Acknowledgements}

This study is produced from the first author's $\mathrm{PhD}$ thesis. This study was presented as a poster in the $18^{\text {th }}$ International Veterinary Medicine Students Scientific Research Congress, Istanbul, Turkey, 2-4 May, 2017 and in Ecology 2017 Symposium, Kayseri, Turkey, 11-14 May, 2017.

\section{Financial Support}

This research is funded by Scientific Research Projects Coordination Unit of Istanbul UniversityCerrahpaşa (Project number: 40786).

\section{Ethical Statement}

This study was approved by the Istanbul University Animal Experiments Local Ethics Board (Decision no: 2013/120)

\section{Conflict of Interest}

The authors declared that there is no conflict of interest.

\section{References}

1. Ahmed HA, El-Hofy FI, Shafik SM, et al (2016): Characterization of virulence-associated genes antimicrobial resistance genes, and class 1 integrons in Salmonella enterica Serovar Typhimurium isolates from chicken meat and humans in Egypt. Foodborne Pathog Dis, 13, 281-288.

2. Alcaide E, Martinez JP, Garay E (1983): Comperative study on Salmonella isolation from sewage contaminated natural waters. J Appl Microbiol, 56, 365-371.

3. Chiu CH, Ou JT (1996): Rapid identification of Salmonella serovars in feces by specific detection of virulence genes, invA and spvC, by an enrichment broth culture-multiplex PCR combination assay. J Clin Microbiol, 34, 2619-2622.

4. Chuanchuen R, Ajariyakhajorn K, Koowatananukul C, et al (2010): Antimicrobial resistance and virulence genes in Salmonella enterica isolated from dairy cows. Foodborne Pathog Dis, 7, 63-69.

5. Clinical and Laboratory Standards Institute (2015): Performance Standards for Antimicrobial Disk and Dilution Susceptibility Tests for Bacteria Isolated from Animals; Informational Supplement $3^{\text {rd }}$ ed. CLSI supplement Vet01S, Wayne, PA

6. Clinical and Laboratory Standards Institute (2016): Performance Standards for Antimicrobial Susceptibility Testing. $26^{\text {th }}$ ed. CLSI supplement M100S. Wayne, PA

7. Dakman A, Yapıcıer Şahan Ö, Yaşarer A, et al (2017): First isolation of Salmonella Hessarek from Sturnus vulgaris in Turkey: A case report. Kafkas Univ Vet Fak Derg, 23, 343-346.

8. Das A, Hari SS, Shalini U, et al (2012): Molecular screening of virulence genes from Salmonella enterica isolated from commercial food stuffs. Biosci Biotech Res Asia, 9, 363-369.

9. Donkersgoed JV, Graham T, Gannon V (1999): The prevalence of verotoxins, Escherichia coli O157:H7, and Salmonella in the feces and rumen of cattle at processing. Can Vet J, 40, 332-338.

10. Duffy G, Cloak OM, O'Sulivan MG, et al (1999): The incidence and antibiotic resistance profiles of Salmonella spp. on Irish retail meat products. Food Microbiol, 16, 623631.

11. Eyigor A, Carli KT, Unal CB (2002): Implementation of real-time PCR to Tetrathionate Broth enrichment step of Salmonella detection in poultry. Lett Appl Microbiol, 34, $37-41$.

12. Fluckey WM, Loneragan WG, Warner R, et al (2007): Antimicrobial drug resistance of Salmonella and Escherichia coli isolates from cattle feces, hides and carcasses, J Food Prot, 70, 551-556.

13. Guerra B, Soto SM, Argüelles JM, et al (2001): Multidrug resistance is mediated by large plasmids carrying a class 1 integron in the emergent Salmonella enterica Serotype [4, 5, 12: i:-]. Antimicrob Agents Chemother, 45, 1305-1308. 
14. Güleșen R, Levent B, Sevindi DF, et al (2010): 2010 yılında serotiplendirilen Salmonella suşlarının değerlendirilmesi. Available at: http://www. Tmconline.org/userfiles/sunumlar/10 Kas/SB-16.pdf (Accessed February 02,2018)

15. Jensen AN, Sorensen G, Baggesen DL, et al (2003): Addition of Novobiocin in pre-enrichment step can improve Salmonella culture protocol of modified semisolid Rappaport-Vassiliadis. J Microbiol Methods, 55, 249-255.

16. McEvoy JM, Doherty AM, Sheridan JJ, et al (2003): The prevalence of Salmonella spp. in bovine faecal, rumen and carcass samples at a commercial abattoir. J Appl Microbiol, 94, 693-700.

17. Murinda SE, Nguyen LT, Nam HM, et al (2004): Detection of sorbitol-negative and sorbitol-positive shiga toxin-producing Escherichia coli, Listeria monocytogenes, Campylobacter jejuni, and Salmonella spp. in dairy farm environmental samples. Foodborne Pathog Dis, 1, 97-103.

18. Murugkar HV, Rahman H, Dutta PK (2003): Distribution of virulence genes in Salmonella serovars isolated from man and animals. Indian J Med Res, 117, 6670

19. Notingham PM, Urselman AJ (1961): Salmonella infection in calves and other animals. New Zeal J Agr Res, 4, 449-460.

20. Oliveira SD, Rodenbusch CR, Ce MC, et al (2003): Evaluation of selective and non-selective enrichment PCR procedures for Salmonella detection. Lett Appl Microbiol, 36, 217-221.

21. Özsan K, Aksoycan N, Fazlı A, et al (1971): Memleketimizde ilk defa tespit edilen S. Berta, S. Lindenburg ve S. San-Diego serotipleri. Mikrobiyol Bul, 5, 128-130.

22. Palmera-Suarez R, Garcia P, Garcia A, et al (2007): Salmonella Kottbus outbreak in infants in Gran Canaria (Spain), caused by bottled water, August - November 2006. Euro Surveill, 12, 3235.

23. Pangoli P, Dje Y, Ahmed O, et al (2008): Seasonal incidence and moleculer characterization of Salmonella from dairy cows, calves and farm environment. Foodborne Pathog Dis, 5, 87-96.

24. Retamal P, Castillo-Ruiz M, Mora GC (2009): Characterization of $\mathrm{mgtC}$, a virulance factor of Salmonella enterica serovar Typhi. Plos One, 4, e5551.

25. Sanchez-Jimenez MM, Cardona-Castro N, Canu N, et al (2010): Distribution of pathogenicity islands among Colombian isolates of Salmonella. J Infec Dev Ctries, 4, 555-559.

26. Soto SM, Rodriquez I, Rodicio MR, et al (2006): Detection of virulence determinants in clinical strains of Salmonella enterica serovar enteritidis and mapping on macrorestriction profiles. J Med Microbiol, 55, 365-373.

27. Toboldt A, Tietze E, Helmuth R, et al (2014): Molecular epidemiology of Salmonella enterica serovar Kottbus isolated in Germany from humans, food and animals. Vet Microbiol, 170, 97-108.

28. Töreci K, Erdem B, Öngen B (2013): Türkiye'de 2011 yll sonuna kadar izolasyonu bildirilen Salmonella serovarlart. Mikrobiyol Bul, 47, 442-460.

29. Warnick LD, Kaneene JB, Ruegg PL, et al (2003): Evaluation of herd sampling for Salmonella isolation on Midwest and Northeast US dairy farms. Prev Vet Med, 60, 195-206.

30. Wells SJ, Fedorka-Cray PJ, Dargatz DA (2001): Fecal shedding of Salmonella spp. by dairy cows on farm and at cull cow markets. J Food Protec, 64, 3-11.

31. WHO (2010): Laboratory protocol: Isolation of Salmonella spp. from food and animal faeces. Available at: http://antimicrobialresistance.dk/CustomerData/Files/Folders/ 6-pdf-protocols/63_18-05-isolation-of-salm-220610.pdf (Accessed December 23, 2019)

32. WHO (2010): Laboratory protocol: Biochemical identification of Salmonella and Shigella using an abbreviated panel of tests. Available at: https://www.researchgate.net/publication/242575055_ Biochemical_Identification_of_Salmonella_and_Shigella_ Using_an_Abbreviated_Panel_of_Tests (Accessed December 23, 2019) 